\title{
Use of a morcellized fragment of bone as a bone graft in a femoral fracture repair
}

\section{Uso de fragmento ósseo morcelizado como enxerto ósseo no reparo de fratura femoral ${ }^{*}$}

\author{
Mayara Eggert,, ${ }^{* *}$ Lucas Lubasinski Daniel, ${ }^{* *}$ Mayron Tobias da Luz, ${ }^{* *}$ Veronica Mollica Govoni, ${ }^{* *}$ Tilde Rodrigues Froes, ${ }^{* * *}$ \\ José Fernando Ibanez $z^{* * *}$
}

\begin{abstract}
As one of the most frequent reasons for presentation at the orthopedic services in veterinary practice, long bone fractures need bone continuity for consolidation to take place. This case report has demonstrates the use of a morcellized fragment of bone as a bone graft in a femoral fracture with major bone loss. A mixed-breed adult cat with a segmental femoral fracture with a large longitudinal fissure in the central bone fragment was submitted to an interlocking nail osteosynthesis. During the procedure a fracture occurred along the fissure resulting in two bone fragments with significant bone loss. Fragments were morcellized and applied over the defect to act as a bone graft. By the $15^{\text {th }}$ day after the surgery, the cat had a normal gait and showed no pain response, and bone consolidation occurred after 7 months. Once harvesting of humeral, femoral and tibial bone grafts can be frustrating in cats, resulting in just small amounts of bone, the morcellation of the central fragments was vital to provide sufficient graft to cover the big defect in the femoral shaft. The authors suggest that autologous fresh morcellized cortical bone fragments can be an adjunct to the treatment of comminuted fractures in cats, as an alternative to more traditional repairs of comminuted fracture.
\end{abstract}

Keywords: bone graft, femur fracture, osteoconduction.

\section{Resumo}

Fraturas de ossos longos necessitam de continuidade óssea para que a consolidação ocorra. Este relato de caso tem como objetivo demonstrar o uso de um fragmento ósseo morcelizado com a função de enxerto ósseo em uma fratura de fêmur com presença de uma grande falha óssea entre os fragmentos. Um gato adulto, sem raça definida, com uma fratura múltipla em fêmur com presença de uma fissura longitudinal no fragmento central foi submetido à osteossíntese com uso de haste bloqueada. Durante o processo, ocorreu uma fragmentação a partir da fissura, o que resultou na presença de dois fragmentos ósseos com uma grande porção de perda óssea entre os dois. Os fragmentos ósseos restantes do fragmento central foram morcelizados e aplicados no defeito para atuar com enxerto ósseo. Quinze dias após a cirurgia o paciente apresentou apoio normal e ausência de dor, e consolidação óssea ocorreu em 7 meses pós operatórios. Uma vez que a coleta de enxerto nos gatos resulta em pouca quantidade de osso, a morcelização do fragmento central foi vital para promover enxerto suficiente para cobrir o defeito ósseo. Os autores sugerem que o uso de enxerto cortical autólogo fresco morcelizado pode ser um adjuvante no tratamento de fraturas cominutivas em gatos, como um tratamento alternativo à terapia convencional.

Palavras chave: enxerto ósseo, fratura femoral, osteocondução.

\section{Introducion}

Long bone fractures are one of the most frequent reasons for presentation at the orthopedic services in veterinary practice, and are normally the result of high impact injuries. Fractures of the femur can be repaired using an interlocking nail technique, which provides stability against axial forces, overcoming the limitations of intramedullary pin use (Beale, 2004; Piorek et al., 2012). The fact that locking nails are placed over the biomechanical axis of the bone explains its advantages upon other types of implants (Larin et al., 2001; Romano et al., 2008).
The fracture repair process encompasses a sequence of cell events that starts at the moment of injury, and local bone continuity is necessary for consolidation to occur. The use of bone grafts assists consolidation in comminuted fractures or fractures with major defects (Miranda et al., 2005).

Bone grafts have four important functions ie to provide: progenitor cells, osteoinductive factors, osteoconductive matrix and structural support (Laurencin et al., 2006). Autologous cancellous bone grafts are the gold standard of bone grafting as they are rapidly incorporated, have potent osteogenic and osteoinductive properties, and provide the cell components

*Recebido em 17 de junho de 2016 e aceito em 26 de maio de 2020.

**Universidade Federal do Paraná, Programa de Residência Médica Multiprofissional, Departamento de Medicina Veterinária, Curitiba, Paraná, Brasil.

***Universidade Federal do Paraná, Departamento de Medicina Veterinária, Curitiba, Paraná, Brasil.

Autor para correspondência: Mayara Eggert may@yahoo.com.br 
and extracellular bone matrix proteins that can accelerate bone regeneration (Laurencin et al., 2006). Cancellous bone grafts do not provide support, but this fact is compensated for by their huge osteogenic capacity that promotes rapid bone neoformation in the fracture focus and contributes to rapid fracture stabilization (Dias et al., 2013).

Along history of orthopedic practice has been confirmed the efficacy of autogenous bone grafting, but problems such as the limited supply associated with autogenous bone harvesting remain (Yoneda et al., 2005). This case report has demonstrates the use of a morcellized fragment of bone as a bone graft in a femoral fracture with major bone loss, as an alternative to more traditional repairs of comminuted fracture.

\section{Case report}

A mixed-breed adult cat with unknown medical history was admitted to the veterinary hospital of the Federal University of Paraná with abnormal movement of the right femur after a traffic accident. Radiographs showed a segmental femoral fracture with a large longitudinal fissure in the central bone fragment.

After the initial stabilization, the team proceeded to surgery. As pre-anesthetic medications was administered intramuscular acepromazine $0,05 \mathrm{mg} / \mathrm{Kg}$ and methadone $0,2 \mathrm{mg} / \mathrm{Kg}$, the induction was made with Propofol $4 \mathrm{mg} / \mathrm{Kg}$, and the maintenance with isoflurane. For analgesia, was performed an epidural block, using lidocaine $0,25 \mathrm{mg} / \mathrm{Kg}$, bupivacaine $0,25 \mathrm{mg} / \mathrm{Kg}$ and morphine 0,1 mg/Kg. Carprofen 2,2 mg/Kg and ceftriaxone $30 \mathrm{mg} / \mathrm{Kg}$ was administered, subcutaneous and intravenous respectively, prior to surgery as adjuvant therapy.

Surgery was performed one day after admission. Intended surgery was placement of a $4.5 \mathrm{~mm}$ diameter, $80 \mathrm{~mm}$ interlocking nail, by a Open But Do Not Touch approach. During pin insertion, a further fracture of the central fragment of bone split this fragment into two pieces. The bone fragment was morcellized and used at the site of the defect as a corticocancellous bone graft. The interlocking nail was fixed with 2 screws in each of the distal and proximal fragments, and the incision closed routinely. Radiographs were taken immediately after the procedure to confirm the position of the nail and screws and bone alignment, as seen in Figure 1.

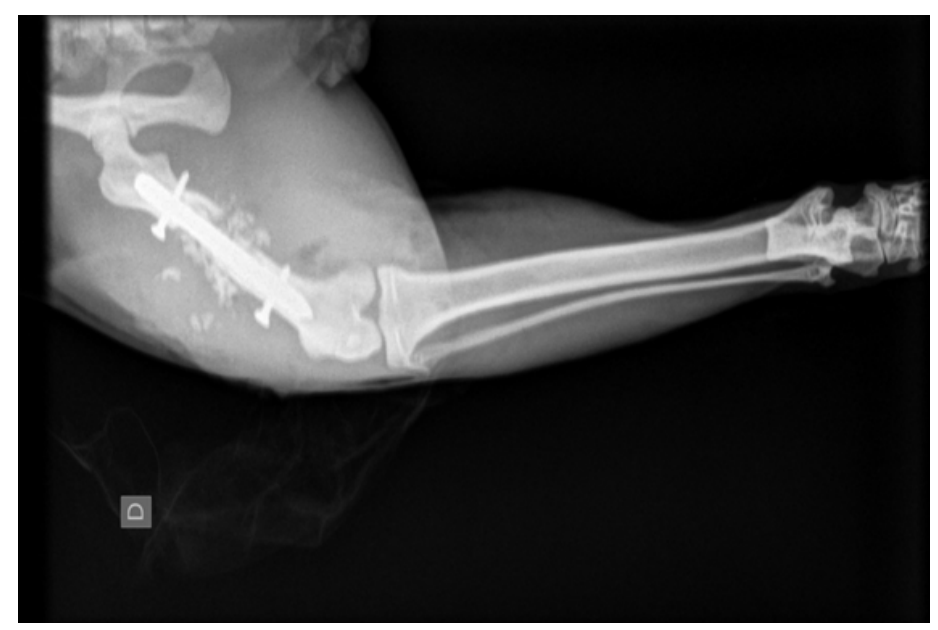

Figure 1. Radiograph taken immediately after surgery showing good bone alignment and the presence of morcellated bone instead of the central fragment
By the $15^{\text {th }}$ day after the surgery, the cat had a normal gait showed no pain response, even on palpation of the area. Follow-up radiographs were taken after two and seven months.

\section{Discussion}

Biological osteosynthesis concept argues that soft tissue protection and the restoration of blood supply to bone fragments are more important than anatomical reconstruction in the treatment of long bone shaft fractures (Horstman et al., 2004) Interlocking nails fully support this concept and can be used to stabilize fractures of femoral, tibial and humeral shafts, with good return of function (Piorek et al., 2012). In a study by Duhautois (2003), 112 patients undergoing interlocking nail osteosynthesis were evaluated: return of function was reported as good or excellent in 16 cases. The authors suggest that this success rate is due to the placement of progressively larger nails to enlarge the medullary canal.

In this case, the fracture characteristics determined that the implant of choice was the interlocking nail. The selection of implant depends upon the relationship of the smallest diameter of the intramedullary space and the length of the bone, which limits the use of interlocking nails in cats to the lengths between $0.68 \mathrm{~mm}$ and $134 \mathrm{~mm}$ and the diameter between 4 and $4.7 \mathrm{~mm}$ (Larin et al., 2001). In this case a nail diameter of $4.5 \mathrm{~mm}$ was selected after measurements made on the radiographs showed the narrowest portion of the patient's medullary canal to be $5.0 \mathrm{~mm}$. However, errors in measurement may occur due to radiographic distortion (Bhat et al., 2006), and the real diameter of the canal may have been overestimated. Attempts to place too large a nail can lead to fracture of the bone fragment during nail insertion and this may have been the cause of intra-surgical fracture in this case.

Bridging the site of a comminuted fracture helps to reduce interfragmentary gap strain, once it is distributed between all fragments over the distance between the pieces of bone. In contrast, when fracture fragments are reconstructed interfragmentary strain is concentrated between fragment gaps (Hulse et al., 2000). This mechanical advantage of interlocking nails is important given the comminuted nature of our case report. It has been suggested that interfragmentary strain is reduced between the fragments of a comminuted fracture treated biologically because micromotion is distributed over a greater area (Marsell \& Einhorn, 2011). Horstman et al. (2004) has demonstrated that the rigidity of the interlocking nail optimize this mechanical environment which along with preservation of the soft tissues and fracture hematoma, are the responsible for the differences in healing times between anatomical and biological approaches fractures treated with this type of implant. The central fragments were morcellized to act as a corticocancellous autograft. According to Denny \& Butterworth (2006) harvesting of humeral, femoral and tibial bone grafts is frustrating in cats, resulting in just small amounts of bone, especially in adult animals. Therefore, the morcellation of the central fragments was vital to provide sufficient graft to cover the big defect in the femoral shaft, since the degree of comminution can be related to non unions in feline femur fractures (Nolte et al., 2005).

At the time of follow-up radiographs taken at 2 months, bone callus was visible, and there was a mixed proliferative and lytic bone density suggesting remodeling was occurring. 
The radiographs taken at 7 months showed almost complete superficial ossification, with the fracture lines almost obscured, as seen in Figure 2. A radiolucent area adjacent to the nail persisted; this may have been related to the presence of the nail and there was no evidence that this was interfering with bone consolidation. At follow up 12 months after surgery the patient has a normal gait the implant remains in place.

\section{Conclusion}

This case reports a morcellized fragment of bone acting as an autologous corticocancellous bone graft in a feline femoral fracture with major bone loss, when combined with an interlocking nail. This technique may provide an alternative to more conventional treatments for comminuted fractures in the cat.

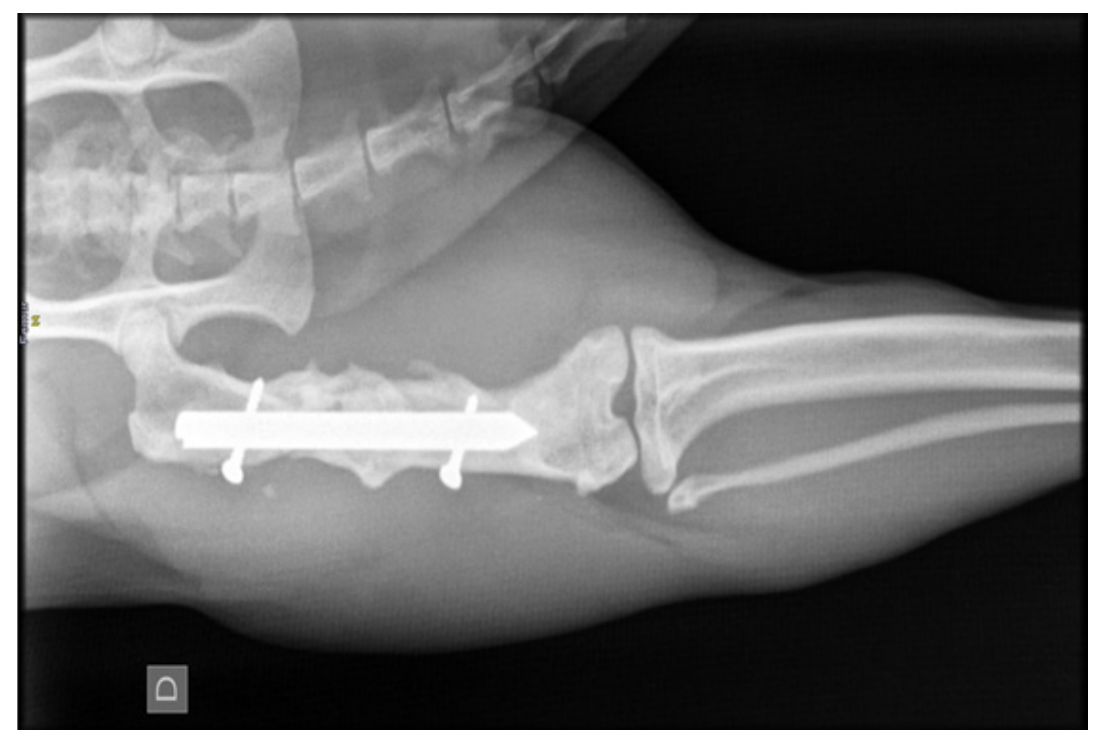

Figure 2: Radiograph taken after seven months of osteosynthesis showing almost complete superficial ossification, note fracture lines are almost obscured

\section{References}

BHAT, A.K.; RAO, S.K.; BHASKARANAND, K. Mechanical failure in intramedullary interlocking nails. Journal of Orthopaedic Surgery, v.14, n.2, p.138-41, 2006.

BEALE, B. Orthopedic Clinical Techniques Femur Fractures Repair. Clinical Techniques in Small Animal Practice, v.19, p.134150, 2004.

DENNY, H.R.; BUTTERWORTH, S.J. Bone Grafts In: DENNY, H. R.; BUTTERWORTH, S. J. A Guide to Canine and Feline Othopaedic Surgery 4. ed. [S.I.] : Blackwell Science, 2006, p.14-18.

DIAS, M.I.R.; SOUSA, C.M.P.; CARVALHO, P.M.P.; LEMPEK, M.R.; VIEGAS, C.A.A.; AZEVEDO, J.M.T. Enxertos e substitutos ósseos em cirurgia ortopédica reconstrutiva nos animais de companhia - Uma breve revisão. Revista Brasileira de Medicina Veterinária, v.4, n.35, p.339-350, 2013.

DUHAUTOIS, B. Use of Veterinary Interlocking Nails for Diaphyseal Fractures in Dogs and Cats: 121 Cases. Veterinary Surgery, v.32, p.8-20, 2003.

HORSTMAN, C.L.; BEALE, B.S.; CONZEMIUS, M.G.; EVANS, R. Biological Osteosynthesis Versus Traditional Anatomic Reconstruction of 20 Long-Bone Fractures Using an Interlocking Nail: 1994-2001. Veterinary Surgery, v.33, p.232-237, 2004.

HULSE, D.; FERRY, K.; FAWCETT, A.; GENTRY, D.; HYMAN, W.; GELLER, S.; SLATER, M. Effect of intramedullary pin size on reducing bone plate strain. Veterinary and Comparative Orthopaedics and Traumatology, v.13, p.185-190, 2000.

LARIN, A.; EICH, C.S.; PARKER, R.B.; STUBBS, W.P. Repair of diaphyseal femoral fractures in cats using interlocking intramedullary nails: 12 cases (1996-2000). Journal of American Veterinary Medicine Association, v.219, n.8, p.1098-1104, 2001.
LAURENCIN, C:; KHAN, Y: EL-AMIN, S.F. Bone Graft Substitutes. Expert Review of Medical Devices, v.3, n.1, p.49-57, 2006.

MARSELL, R.; EINHORN, T.A. The biology of fracture healing. Injury, v.42, n.6, p.551-555, 2011.

MIRANDA, E.S.; CARDOSO, F.T.S.; MEDEIROS, J.F.F.; BARRETO, M.D.R.; TEIXEIRA, R.M.M.; WANDERLEY, A.; Fernandes, K.E. Estudo experimental comparativo no uso de enxerto ósseo orgânico e inorgânico no reparo de fraturas em rádio de coelhos. Acta Ortopédica Brasileira, v.5, n.13, p.245-248, 2005.

NOLTE, D.M.; FUSCO, J.V.; PETERSON, M.E. Incidence of and predisposing factors for nonunion of fractures involving the appendicular skeleton in cats: 18 cases (1998-2002). Journal of the American Veterinary Medical Association, v.226, n.1, p.77-82, 2005.

PIÓREK, A.; ADAMIAK, Z.; MATYJASIK, H.; ZHALNIAROVICH, Y. Stabilization of Fractures with the Use of Veterinary Interlocking Nails. Pakistan Veterinary Journal, v.32, n.1, p.10-14, 2012.

ROMANO, L.; FERRIGNO, C.R.A.; FERRAZ, V.C.M.; NINA M.I.D.; ITO, K.C. Evaluation of the use of interlocking nail and transcortical blockade for the repair of diaphyseal fractures of the femur in cats. Pesquisa Veterinária Brasileira, v.28, p.201-206, 2008.

YONEDA, M.; TERAIA, H.; IMAIA, Y.; OKADAB, T.; NOZAKIC, K.; INOUED, H.; MIYAMOTOA, S.; TAKAOKA, K. Repair of an intercalated long bone defect with a synthetic biodegradable bone-inducing implant. Biomaterials, v.26, p.5145-5152, 2005. 